\title{
POETRY PAGE
}

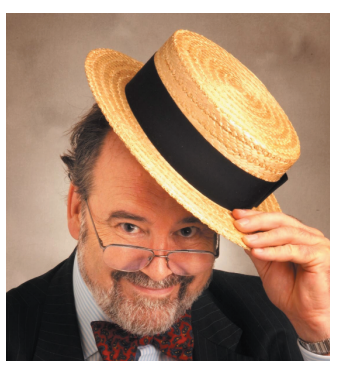

\section{'Betjeman's' Salute to the Faculty at the Fellows' Dinner, 7 June 2006}

Jim Drife, FRCOG

My dear FFP! My dear FFP!

Furnished with food, what an honour for me To rise in response to the President's call And say a few words in this fine Nuffield Hall.

Named after Lord Nuffield, whose portrait is here: Once plain Mr Morris, then later a peer

Who showered the medical world with largesse And they, in return, made him FRCS.

His cars were so English. None could be finer! The best of them all was the old Morris Minor: When you parked with your girl, be she oh-so-receptive Its severe lack of space was a sure contraceptive.

My dear FFP! My dear FFP!

Or to use your full name, FFPRHC

Of the RCOG, here in NW1

(I do like initials - they're ever such fun).

Tonight you are welcoming many a new fellow Relaxing for once - in fact, feeling quite mellow But proud, I feel sure - and with justification To join your magnificent organisation.

Born in the 90s - 93 I've been told So this year the Faculty's thirteen years old. As family planners we know what that means: The Faculty's entered the terrible teens.

I've heard that at Council now, everything stops If someone says, "Did you see Top of the Pops?" Impassioned discussions get way out of hand When it comes to the merits of Franz Ferdinand.

It's the hormones, you know. They keep coming in surges. I seem to remember all sorts of strange urges From my endocrine system, way back in the past: My advice is, "Enjoy it, it's not going to last".

So we're very impressed by the Faculty's youth But the specialty's rather more long in the tooth. When did it all start? Does anyone know?

It must have been almost a century ago.

Was it Marie Stopes' clinic that first set the scene Or her Married Love published in 1918 ?

Think hard and decide - don't let your brains seize up And then you can plan a centenary knees-up.

Though "knees-up" perhaps isn't quite the right phrase You could mark the event in appropriate ways.

Do something big. In fact, do something vast:

Have all of your 12,000 members march past
All holding aloft their vasectomy kits.

The media, I'm sure, would be tickled to bits With cheering spectators all lining the route And your President up there to take the salute.

But that's for the future, my dear FFP. Tonight is much cosier, just you and me In our optional black ties and elegant dresses With four Honorary Fellows and two Baronesses:

Peeresses from Yorkshire - distinction indeed! But one comes from Dewsbury and one comes from Leeds. There are heated debates in the House coming up: Who will win Rugby League's Powergen Challenge Cup?

Miss Melanie Davies is here as our guest. Among medical women, she's one of the best! So Melanie, congratulations again

From one of that dying breed - medical men.

But really, new Fellows, tonight is for you. Recognising your worth is the least we can do. Back home in your clinics you don't seek renown: You work in unfashionable parts of the town

With clients who sometimes make life quite a toil: They don't want the cap and they don't like the coil They came off the pill "cause it gives you blood clots And an Implanon brought their best friend out in spots.

The calendar method? - Please, do me a favour! They're allergic to condoms (except strawb'rry flavour). With Depo their tummy came right out to here They were size 22 for the rest of the year.

They had a Mirena and then had it out. They'd have their tubes tied but they're still full of doubt And the minipill gives them a pain in the chest. So apart from that, doctor, what do you suggest?

I think I can safely say we've all been there! But we do love it, working in women's health care. Applying the guidelines and giving advice And most patients (or clients) are awfully nice.

But without our own Faculty, where would we be? No training, no Journal, no DFFP.

No words of advice to the right politician. No Council, no Corin, no President Kishen.

Madam President, councillors, fellows and friends: We've now reached the point at which this poem ends. It's good health to you all and it's goodnight from me As I take off my hat to my dear FFP.

\section{Editor's Note}

This poem was composed and performed by Professor James Owen Drife on the occasion of the Faculty's Fellowship Ceremony Dinner held at the Royal College of Obstetricians and Gynaecologists in London, UK on 7 June 2006. The Editor felt the Journal's readers might like to share the experience, although nothing could compare with seeing the performance 'live', complete with straw hat and appropriate accent. [NB. When not engaged in composing and reciting poetry, Professor Drife's day job is Professor of Obstetrics and Gynaecology at the University of Leeds, Leeds, UK.] 
JOURNAL EDITOR QUERIES

1 What might be a suitable header? ('Poetry Page' has been used temporarily).

2 Is the page layout appropriate? (we've never had a poem in the journal before). NB. The punctuation hasn't been greatly amended from that appearing in the original text.

3 Should we include author full name and brief affiliation.

Is the wording of the footnote appropriate? 